the patient is unlikely to derive much encouragement from " investigations with radioisotopes of sodium, potassium, and chlorine show that movements of the ions through capillary walls and cell membrane are best explained in terms of active transfer ", nor may he altogether share the view that " the diabetic state gives rise to interesting organic changes ".

The book is poorly written, and when the author leaves the clinical field his text consists of snippets from the literature with little attempt to evaluate the material or to weave it into a coherent whole. It is not, therefore, suitable for the internist.

Of the six illustrations purporting to show pathological changes in the retina, only one (Fig. 10) could be accepted as demonstrating the claims of the legend, and the simplified diagrams of metabolic pathways are probably of little value to the reader for whom they were designed. The author presents no original data and his suggestions for future research, such as "Nutrition and disease and how they affect the body tissues", are so all-embracing and vast in scope as to appal the keenest research worker seeking here for inspiration. It is unfortunate that the book cannot be recommended, for it is beautifully produced and singularly free from printer's errors.

Viral and Rickettsial Diseases of the Skin, Eyes, and Mucous Membranes of Man. By H. Blank and G. RaKe. 1955. Pp. 285, 63 figs, 6 col. pl. Churchill, London. (60s.).

In a short text the authors have attempted to give an outline of the main viral infections occurring in these sites in man, with the inevitable result that many diseases which might have been mentioned are omitted. However, those conditions with which the book deals are presented in a readable manner and should prove instructive to those requiring an introduction to the subject.

A serious criticism of the work is the arrangement and classification of the material. Thus there seems little merit in separating Psittacosis from the remainder of Chlamydozoacae, while it is unusual to find dengue and infectious mononucleosis included with the exanthemata.

The book is extremely well produced and the illustrations are of a very high standard. A series of the references considered to be of greatest importance is added at the end of each section.

\title{
NOTES
}

\section{INTERNATIONAL Council of OphThaLmology}

The following were present at a meeting held in Paris on May 7, 1955: Duke-Elder (President), Berens (Vice-President), Hartmann (Secretary), Amsler (Treasurer), Bietti (International Organization against Trachoma), Franceschetti (Association for the Prevention of Blindness), Samuels (President of the last Congress), Coppez (President of the next Congress), Arruga (Spain), Charamis (Greece), Palomino Dena (Mexico), Paufique (France), Thiel (Germany), Weve (Holland).

Apart from dealing with current business, the following are the most important decisions taken by the Council.

1. Index Ophthalmologicus.-In accordance with the Statutes of the Council, an Index Ophthalmologicus had been published at the time of the International Congress in 1954. The sale of the Index had, however, up to the present been very slow, involving the Council in considerable expense. It was thought that this was due to the fact that it was insufficiently known. The Index contains the names and addresses of ophthalmologists in most countries of the world and information on hospitals, journals, and ophthalmological societies in these countries. It may 
be obtained for the price of $£ 1$ (\$2.75), from Dr. A.C. Copper, Coehoornsingel 42 , Zutphen, Holland. Despite the disappointing sales the Council decided to publish a new Index at the time of the Congress in 1958, believing that, once ophthalmologists generally came to know the value of the book, it would eventually become a paying proposition.

2. International Dictionary of Ophthalmological Terms.-This dictionary is being prepared by Alvaro, Amsler, Bietti, and Duke-Elder, and it is hoped that it will be available before the time of the next International Congress. In the dictionary, ophthalmic terms will be translated into six languages: English, German, Spanish, French, Italian, and Latin.

3. Sub-Committee FOR THE Gonin Medal.-The term of office of the old committee having expired, the following were elected:

Ex-officio Members: Duke-Elder, Streiff.

Members: François, Friedenwald, Karpe, Müller, and Nordmann;

Substitute Members: Eliott, Lo Cascio, Malbran, Ida Mann, and Nakamura.

4. COMmittee for the Standardization of Colour Vision.-At its last meeting the International Federation of Ophthalmological Societies had decided that examination of colour vision in transport workers should be carried out with the pseudo-isochromatic tables, and for this purpose had initially accepted the Ishihara charts. . It was, however, decided that any new tests which appeared from time to time should be recommended if they were considered equally suitable. A committee was formed to deal with this matter, consisting of L.C. Thomson (Medical Research Council and Institute of Ophthalmology, London), Yves Le Grand (Collège de France, Paris), Louisa Sloane (Wilmer Institute, Baltimore), and J. Zanen (Brussels).

5. RoAD SAFETY.-A committee, consisting of Bietti, Goldmann, and Dubois-Poulsen, was formed by the Council to study the visual danger to drivers of roadside advertising hoardings and the placing of roadside objects at regular intervals. The questions raised were, in the first case, how far advertisements caused the driver to divert his eyes from the road, and in the second, what was the danger of rhythmic stimulation of the retina in causing nervous symptoms in some persons.

6. XVII InTERnational Congress Montreal-New York 1954.-The Acta of the XVII International Congress, to be published in three volumes, should appear towards the end of 1955.

The next meeting of the Council will be held in England in the spring of 1956.

\section{International Organization Against Trachoma}

45, Lincoln's Inn Fields, London, W.C.2.

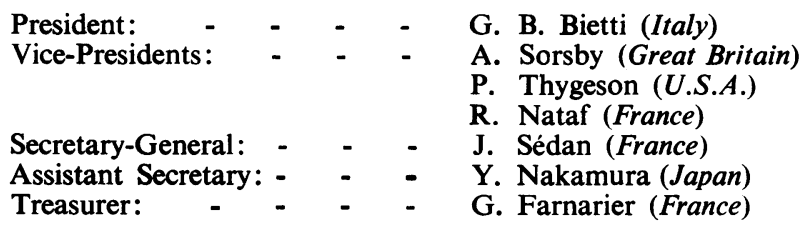

A meeting will be held in Madrid in 1956 on the occasion of the Second Congress of the Société Latine d'Ophtalmologie.

\section{OBITUARY}

\section{Edward Leslie Gault}

THE death is announced of Dr. Edward Leslie Gault in Melbourne on December 18, 1954, at the age of 92 years. Dr. Gault was born in Manchester in 1863 and his family migrated to Victoria in $\mathbf{1 8 7 0 . ~ H e ~ g r a d u a t e d ~ a t ~ t h e ~ U n i v e r s i t y ~ o f ~ M e l b o u r n e , ~}$ and, proceeding to London, was for a time on the resident staff of Moorfields Hospital. 